\title{
Peningkatan Kompetensi Guru PPKN SMP Dalam Melaksanakan Penilaian Autentik Berdasarkan Kurikulum 2013
}

\author{
Komarudin $^{1}$; Sarkadi ${ }^{2}$; Ahmad Tarmiji Alkhudri ${ }^{3}$ \\ 1,2 Program Studi PPkn Fakultas Ilmu Sosial Universitas Negeri Jakarta \\ ${ }^{3}$ Program Studi Pendidikan Sosiologi Fakultas Ilmu Sosial Universitas Negeri Jakarta \\ komarudinsahid@gmail.com; sarkadi09@yahoo.co.id; alkhudri47@gmail.com
}

\begin{abstract}
Authentic assessment has a strong relevance to the scientific approach to learning that is in accordance with the demands of the 2013 Curriculum. Its existence is very important for teachers to understand. However, in reality there are still teachers who do not understand authentic assessment as an important part of the implementation of the 2013 curriculum. Therefore, it is very important to do community service activities about authentic assessment, especially for PPKn subject teachers at the Junior High School level in Indramayu Regency. The form of P2M activities in the form of workshops with problem solving methods rests on cooperative inquiry. The target audience is 45 PPKn teachers at the Junior High School level in Indramayu Regency. The results of P2M activities showed an increase (1) participants' understanding of the basic concepts of authentic assessment with a score (84) after the workshop and (93) after online mentoring; (2) Understanding of authentic assessment according to the 2013 curriculum with the value of (87) after the workshop and (90) after online assistance; (3) the ability to identify the types and authentic assessment instruments with a value (84) after the workshop and (90) after online assistance; (4) development of instruments, authentic assessment rubrics (80) after workshops and (86) after online mentoring.
\end{abstract}

Keywords: Competency Enhancement, PPKn Teachers Junior High School, Authentic Assessment, 2013 Curriculum

\begin{abstract}
Abstrak
Penilaian authentik memiliki relevansi kuat terhadap pendekatan ilmiah dalam pembelajaran yang sesuai dengan tuntutan Kurikulum 2013. Keberadaannya sangat penting dipahami oleh para guru. Namun, dalam kenyataannya masih terdapat guru yang belum memahami penilaian autentik sebagai bagian penting dari implementasi kurikulum 2013. Oleh karena itu, sangat penting dilakukan kegiatan pengabdian kepada masyarakat tentang penilaian autentik, khususnya bagi guru mata pelajaran PPKn Tingkat SMP di Kabupaten Indramayu. Bentuk kegiatan P2M berupa workshop dengan metode pemecahan masalah bertumpu pada cooperative inquiry. Khalayak sasaran adalah guru PPKn Tingkat SMP di Kabupaten Indramayu sebanyak 45 orang. Hasil kegiatan P2M menunjukkan peningkatan (1) pemahaman peserta mengenai konsep dasar
\end{abstract}


DOI: https://doi.org/10.21009/sarwahita.152.07

P-ISSN: 0216-7484

E-ISSN: 2597-8926

penilaian autentik dengan nilai (84) sesudah workshop dan (93) sesudah pendampingan online; (2) Pemahaman penilaian autentik menurut kurikulum 2013 dengan nilai (87) sesudah workshop dan (90) sesudah pendampingan online; (3) kemampuan mengidentifikasi jenis-jenis dan instrumen penilaian autentik dengan nilai (84) sesudah workshop dan (90) sesudah pendampingan online; (4) pengembangan instrumen, rubrik penilaian autentik (80) sesudah workshop dan (86) sesudah pendampingan online.

Kata kunci: Peningkatan Kompetensi, Guru PPKn SMP, Penilaian Autentik, Kurikulum 2013

\section{PENDAHULUAN}

Peningkatan kualitas pembelajaran merupakan konsekuensi logis dari perkembangan dinamika pendidikan dan tugas kependidikan masa kini (Andika, 2011). Guru, dalam hal ini dituntut melakukan pemutakhiran strategi dan konsep-konsep pembelajaran untuk meningkatkan kualitas pembelajaran dan sekaligus sebagai bukti profesionalitasnya (Brookfield, 1990; Killen, 1998; Abdullah, 2009; Kunandar, 2011). Penguatan kualitas dan profesionalitas guru sejatinya sejalan dengan tujuan pendidikan dan kurikulumnya (Soedijarto, 1993; Dakir, 2004; Yulaelawati, 2004; Dimyati dan Mudjiono, 2006; Jihad, 2008; Nasution, 2008). Dalam konteks ini, Kurikulum 2013 menjadi instrumen penting untuk menghasilkan insan Indonesia yang produktif, kreatif, inovatif, afektif melalui penguatan sikap, keterampilan dan pengetahuan yang terintegrasi (Mulyasa, 2013).

Sebagai instrumen pendukung dalam upaya implementasi kebijakan kurikulum 2013, pemerintah kemudian menerbitkan sejumlah peraturan yang menjadi rujukan penerapan Kurikulum 2013, di antaranya adalah peraturan menteri tentang (1) Standar Kompetensi Lulusan (Permendikbud No. 20/2016); (2) Standar Isi Proses (Permendikbud No. 21/2016); (3) Standar Proses (Permendikbud No. 22/2016); (4) Standar Penilaian (Permendikbud No. 23/2016); (5) Kompetensi Dasar dan Struktur Kurikulum mulai jenjang SD/MI sampai jenjang SLTA (Permendikbud No. 24/2016); dan (6) Buku Teks Pelajaran (Permendikbud No. 8/2016).

Dari sini kemudian Kurikulum 2013 diimplementasikan dan hingga saat ini, sudah memasuki lima tahun berjalan. Dalam proses implementasi ini, permasalahan yang terkait dengan pelaksanaan Kurikulum 2013 pada satuan pendidikan sangatlah luas dan kompleks. Salah satunya yang terjadi pada guru-guru PPKn SMP di Kabupaten Indramayu. Mereka belum melaksanakan Kurikulum 2013 secara utuh lantaran beberapa sebab, yang utama terkait dengan minimnya pengetahuan tentang penilaian authentik.

Penilaian autentik memiliki relevansi kuat terhadap pendekatan ilmiah dalam pembelajaran sesuai dengan tuntutan Kurikulum 2013 (Suyanto, 2002). Penilaian authentik 
sangat penting dipahami oleh para guru. Guru dituntut mampu memahami penilaian, dengan tujuan (1) untuk mendiagnosa kekuatan dan kelemahan siswa secara individu; (2) memonitor kemajuan belajar siswa; (3) memberikan kualifikasi dalam memberi nilai prestasi siswa; dan (4) menentukan efektivitas pengajaran, sejauh mana capaian pengetahuan dan keterampilan siswa setelah mengalami proses pembelajaran. Penilaian autentik harus empiris, kontekstual, dipusatkan kepada peserta didik (student-centred, learningoriented), mengedepankan pendekatan mendalam (deep approach), pendekatan strategis (strategic approach) dan proses belajar yang juga autentik (Light dan Cox, 2001; Ormiston, 2011)

Dalam pembelajaran authentik, peserta didik diminta mengumpulkan informasi dengan pendekatan saintifik, memahami aneka fenomena atau gejala dan hubungannya satu sama lain secara mendalam, serta mengaitkan apa yang dipelajari dengan dunia nyata yang di luar sekolah. Secara sosiologis hal ini sejalan dengan logika struktural fungsional Durkheim. Dalam pandangan Durkheim, pembelajaran berfungsi untuk memahami realitas sosial (social fact). Dari sinilah kemudian, peserta didik diharapkan dapat merawat, meligitimasi, mentransformasi, dan mensosialisasikan collective conscience di dalam tatanan masyarakat (Meighan, 1981). Menurut Durkheim upaya tersebut dapat dilakukan dengan cara membentuk segmentasi pengetahuan baik konsep maupun topik yang ada di dalam kurikulum pembelajaran
(Meighan, 1981; Robinson, 1986). Oleh karena itu, segments of knowledge dalam isi kurikulum inilah yang diajarkan kepada peserta didik dengan orientasi untuk menjaga harmonisasi sistem sosial masyarakat yang ada (Turner, 1998).

Sejalan dengan deskripsi di atas, pada pembelajaran authentik, guru harus menjadi "guru authentik." Peran guru bukan hanya pada proses pembelajaran, melainkan juga pada penilaian. Untuk bisa melaksanakan pembelajaran authentik, guru harus memenuhi kriteria tertentu seperti disajikan berikut ini.

1. Mengetahui bagaimana menilai kekuatan dan kelemahan peserta didik serta (etnografi peserta didik dan ruang kelas harus dikuasai).

2. Mengetahui bagaimana cara membimbing peserta didik untuk mengembangkan pengetahuan mereka sebelumnya dengan cara mengajukan pertanyaan dan menyediakan sumberdaya memadai bagi peserta didik untuk melakukan akuisisi pengetahuan.

3. Menjadi pengasuh proses pembelajaran, melihat informasi baru, dan mengasimilasikan pemahaman peserta didik.

4. Menjadi kreatif tentang bagaimana proses belajar peserta didik dapat diperluas dengan menimba pengalaman dari dunia di luar tembok sekolah.

Namun, dalam realitasnya masih banyak guru yang belum memahami penilaian autentik sebagai bagian penting dari implementasi kurikulum 2013. Terkait konteks di atas, guru secara terus menerus dituntut untuk 
DOI: https://doi.org/10.21009/sarwahita.152.07

P-ISSN: 0216-7484

E-ISSN: 2597-8926

belajar melakukan pembaharuan atas ilmu pengetahuan yang dimilikinya agar dapat mendidik dengan baik (Rooijakkers, 1991; Utomo dan Ruijter, 1991). Caranya dapat dilakukan dengan aktif melalui kegiatan-kegiatan workshop pendidikan. Untuk itu, sangat penting dilakukan kegiatan pengabdian kepada masyarakat dengan tema "Peningkatan Kompetensi Guru PPKn SMP dalam Melaksanakan Penilaian Autentik berdasarkan Kurikulum 2013", khususnya Guru mata pelajaran PPKn di Kabupaten Indramayu.

Berdasarkan analisis situasi di atas dapat dirumuskan titik fokus permasalahan mitra, antara lain:

1. Kurangnya pemahaman guru-guru PPKn SMP di Kabupaten Indramayu tentang jenis-jenis penilaian autentik;

2. Kurangnya pemahaman guru-guru PPKn SMP di Kabupaten Indramayu dalam penyusunan instrument autentik;

3. Kurangnya pemahaman guru-guru PPKn SMP di Kabupaten Indramayu dalam menyusun instrumen penilaian autentik yang tepat untuk mengukur masalah kontekstualitas pembelajaran.

Solusi yang tim pengusul tawarkan ialah workshop peningkatan kompetensi guru dalam melaksanakan penilaian autentik berdasarkan Kurikulum 2013. Workshop ini melibatkan peran serta aktif perwakilan guru PPKn SMP seKabupaten Indramayu sebagai peserta. Workshop yang dilakukan mempertimbangkan keterkaitan dan

kecocokan (link and match) antara problem dan program/materi yang ditawarkan (Suryadi, 1998).

\section{METODE PELAKSANAAN}

Metode pemecahan masalah bertumpu pada cooperative inquiry. Khalayak sasaran adalah guru PPKn Tingkat SMP di Kabupaten Indramayu sebanyak 45 orang. Tempat yang digunakan adalah Ruang Laboratorium SMPN 1 Indramayu. Adapun jadwal kegiatan Workshop Penilaian authentik dilaksanakan sejak akhir Oktober November 2018, dan kegiatan intinya dilaksanakan pada hari Senin, 19 November 2018. Mitra yang terlibat dalam Pengabdian kepada Masyarakat ini ialah Dinas Pendidikan Kabupaten Indramayu dan SMPN 1 Indramayu sebagai Tuan Rumah kegiatan. Sebagai mitra dalam kegiatan ini, kontribusi utama Dinas Pendidikan Kabupaten Indramayu antara lain: (1) mengkoordinasikan guru-guru PPKn peserta workshop P2M; (2) menyediakan fasilitas kegiatan; dan (3) membantu pelaksanaan kegiatan pendampingan penyusunan instrumen penilaian autentik serta monev.

\section{HASIL DAN PEMBAHASAN}

\subsection{Pelaksanaan Kegiatan}

Realisasi pemecahan masalah mengenai workshop Peningkatan Kompetensi Guru PPKn SMP dalam melaksanakan penilaian autentik berdasarkan Kurikulum 2013 di Kabupaten Indramayu, disusun dalam kerangka program sebagai berikut: (1) pengamatan dan analisis masalah dalam penilaian autentik, (2) menyusun materi 
DOI: https://doi.org/10.21009/sarwahita.152.07

P-ISSN: 0216-7484

E-ISSN: 2597-8926

yang relevan untuk kegiatan workshop penilaian autentik, (3) menyusun program dan kegiatan pengabdian dalam bentuk workshop penilaian autentik (4) kegiatan inti: memberikan workshop penilaian autentik; pengawasan/pengendalian kegiatan; dan evaluasi proses serta hasil kegiatan.

Pertama, tahap pengamatan dan analisis masalah dalam penilaian authentik. Tahapan ini dilakukan minggu terakhir bulan Oktober 2018. Pengamatan dilakukan secara langsung mengenai potensi sekolah dan guru yang akan menjadi sasaran kegiatan workshop. Setelah dicermati dipilihlah

beberapa sekolah untuk mengirimkan satu orang utusan guru PPKn untuk mengikuti workshop berdasarkan surat undangan dari Kepala Bidang Pembinaan SMP di Kabupaten Indramayu.

Pada tahap pertama ini sebagai mapping awal, Tim P2M mengirimkan angket untuk mengukur problem apa saja yang dialami guru PPKn SMP di Indramayu dalam melaksanakan penilaian autentik. Berikut ini hasil angket yang dikirimkan pada 45 guru PPKN sebelum workshop dilakukan.

Tabel 1. Pemetaan sebelum workshop Peningkatan Kompetensi Guru PPKN SMP dalam Melaksanakan Penilaian Autentik berdasarkan Kurikulum 2013

\begin{tabular}{clcc}
\hline No & \multicolumn{1}{c}{ Muatan Materi } & $\begin{array}{c}\text { Memahami } \\
(\%)\end{array}$ & $\begin{array}{c}\text { Belum memahami } \\
(\%)\end{array}$ \\
\hline 1 & Konsep dasar penilaian autentik & 75 & 25 \\
2 & $\begin{array}{l}\text { Penilaian autentik menurut kurikulum } \\
2013\end{array}$ & 75 & 25 \\
3 & $\begin{array}{l}\text { Jenis-jenis dan instrumen penilaian } \\
\text { autentik }\end{array}$ & 68 & 32 \\
4 & $\begin{array}{l}\text { Pengembangan instrumen, rubrik } \\
\text { penilaian autentik }\end{array}$ & 66 & 34 \\
\hline
\end{tabular}

Kedua, tahap penyusunan materi yang relevan untuk kegiatan workshop. Tahap ini dilakukan pada minggu pertama di bulan November 2018. Materi yang disiapkan antara lain: (1) Konsep dasar penilaian autentik; (2) Penilaian autentik menurut kurikulum 2013; (3) Jenis-jenis dan instrumen penilaian autentik; (4) Pengembangan instrumen, rubrik penilaian autentik, dan presentasi hasil kerja kelompok.
Ketiga, penyusunan program dan kegiatan pengabdian. Tahap ini dilakukan pada minggu kedua bulan November 2018. Sosialisasi kegiatan pengabdian pada awalnya dikomunikasikan kepada Kepala SMPN 1 Indramayu, Bapak Triswanto dan Kepala Bidang Pembinaan SMP, Dinas Pendidikan Kabupaten Indramayu, Bapak Supardo. Berdasarkan surat dari Kepala Bidang Pembinaan SMP, setiap satuan pendidikan diminta mengirimkan 
DOI: https://doi.org/10.21009/sarwahita.152.07

P-ISSN: 0216-7484

E-ISSN: 2597-8926

satu orang guru PPKn untuk mengikuti kegiatan workshop penilaian autentik. Dalam sosialisasi tersebut, tim panitia tidak mendapatkan hambatan berarti. Jumlah peserta yang hadir memenuhi kuota yang diharapkan. Peserta yang hadir berjumlah 45 orang guru PPKN.

Keempat, tahap inti program kegiatan, yaitu memberikan workshop tentang penilaian autentik. Kegiatan ini dilaksanakan pada hari Senin, 19 November 2018. Narasumber dalam workshop ini berjumlah 2 orang yaitu: Dr. Komarudin, M.Si, dan Dr. Sarkadi, M.Si. Moderator yang memandu jalannya kegiatan adalah Dr. Ahmad
Tarmiji A, M.Si. Kegiatan workshop diawali dengan pembukaan acara yang dipandu oleh panitia. Kemudian dilanjutkan dengan Sambutan Kepala Bidang Pembinaan SMP, Dinas Pendidikan Indramayu, H. Supardo, M.Pd., yang mengantarkan materi ceramah tentang Kebijakan Pendidikan di Kabupaten Indramayu.

Setelah pembukaan dan ceramah kebijakan pendidikan di Kabupaten Indramayu oleh H. Supardo, M.Pd, acara dilanjutkan. Workshop dipandu oleh moderator. Berikut ini susunan acara workshop secara terperinci dari mulai pukul 07.00 - 15.00 WIB.

Tabel 2. Rincian Agenda Workshop

\begin{tabular}{|c|c|}
\hline Waktu & Acara \\
\hline $07.00-08.00$ & Registrasi Peserta \\
\hline $08.00-08.10$ & Laporan Ketua Tim P2M PPKn FIS UNJ \\
\hline $08.10-08.25$ & Sambutan Kepala Bidang SMP Dinas Pendidikan Kab. Indramayu \\
\hline $08.25-08.30$ & Doa (dari peserta) \\
\hline \multirow[t]{3}{*}{$08.30-09.30$} & SESI PERTAMA “Konsep dasar penilaian autentik" \\
\hline & Pemateri: Dr. Komarudin, M.Si \\
\hline & Moderator: Dr. Ahmad Tarmiji A., M.Si. \\
\hline $09.30-09.45$ & Coffee Break \\
\hline \multirow[t]{3}{*}{$09.45-10.45$} & SESI KEDUA "Penilaian autentik menurut kurikulum 2013” \\
\hline & Pemateri: Dr. Komarudin, M.Si \\
\hline & Moderator: Dr. Ahmad Tarmiji A., M.Si. \\
\hline \multirow[t]{3}{*}{$10.45-11.45$} & SESI KETIGA “Jenis-jenis dan instrument penilaian autentik” \\
\hline & Pemateri: Dr. Sarkadi, M.Si \\
\hline & Moderator: Dr. Ahmad Tarmiji A., M.Si. \\
\hline $11.45-13.00$ & Ishoma \\
\hline \multirow[t]{3}{*}{$13.00-15.00$} & $\begin{array}{l}\text { SESI KEEMPAT "Pengembangan instrumen, rubrik penilaian } \\
\text { autentik, dan presentasi hasil kerja kelompok" }\end{array}$ \\
\hline & Pemateri: Dr. Sarkadi, M.Si \\
\hline & Moderator: Dr. Ahmad Tarmiji A., M.Si. \\
\hline 15.00 - Selesai & Penutupan \\
\hline Workshop & peserta yang berjumlah 45 orang. Sesi ini \\
\hline
\end{tabular}


DOI: https://doi.org/10.21009/sarwahita.152.07

P-ISSN: 0216-7484

E-ISSN: 2597-8926

serta membuat peserta menjadi lebih termotivasi untuk mengikuti materi yang akan disampaikan. Sesi ini mendapat sambutan yang luar biasa dari peserta, terlihat dari antusiasme peserta mengikuti setiap instruksi yang

pembicara berikan. Antusiasme tersebut terbukti dari hasil rangkaian kegiatan pengabdian masyarakat ini yang mendapatkan respon positif dari para peserta kegiatan.
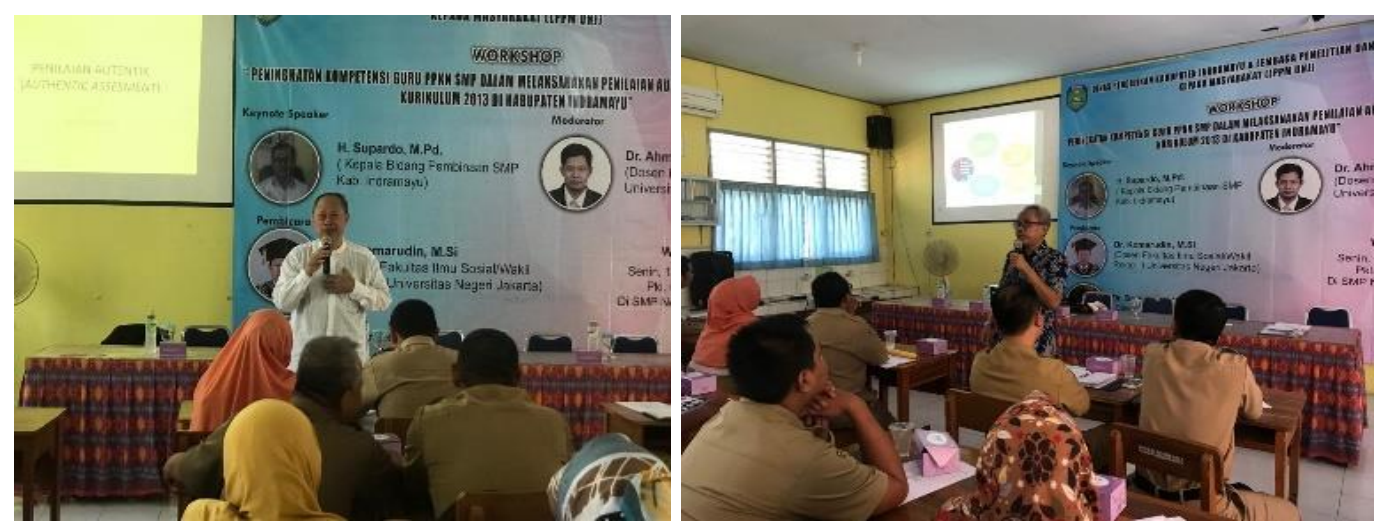

Gambar 1 dan 2. Kedua Narasumber Workshop sedang memamparkan materi disimak dengan antusias oleh peserta

Dalam pelaksanaan kegiatan inti yaitu berupa workshop penilaian autentik, dapat dilaporkan bahwa dalam hal penilaian autentik, guru mempunyai pemahaman yang utuh mengenai pembuatan instrumen penilaian autentik. Hal ini dapat dilihat dari hasil pekerjaan yang mereka lakukan dengan teman sejawatnya maupun dari instrumen penilaian autentik yang dikerjakan selama mengikuti workshop. Peningkatan guru dalam memahami penilaian autentik dinyatakan dalam tabel berikut.

Tabel 3. Peningkatan kompetensi peserta

\begin{tabular}{|c|c|c|c|c|c|}
\hline \multirow[t]{2}{*}{ No. } & \multirow{2}{*}{ Muatan Materi } & \multicolumn{3}{|c|}{ Kompetensi Guru } & \multirow{2}{*}{ Teknik Penilaian } \\
\hline & & $\begin{array}{l}\text { Sebelum } \\
\text { Workshop }\end{array}$ & $\begin{array}{l}\text { Sesudah } \\
\text { Workshop }\end{array}$ & $\begin{array}{c}\text { Pendampingan } \\
\text { Online }\end{array}$ & \\
\hline 1. & $\begin{array}{l}\text { Konsep dasar penilaian } \\
\text { autentik }\end{array}$ & 75 & 84 & 93 & $\begin{array}{l}\text { Diskusi, unjuk } \\
\text { kerja, bimbingan } \\
\text { online }\end{array}$ \\
\hline 2. & $\begin{array}{l}\text { Penilaian autentik } \\
\text { menurut kurikulum } \\
2013\end{array}$ & 75 & 87 & 90 & $\begin{array}{l}\text { Diskusi, unjuk } \\
\text { kerja, bimbingan } \\
\text { online }\end{array}$ \\
\hline 3. & $\begin{array}{l}\text { Jenis-jenis dan } \\
\text { instrumen penilaian } \\
\text { autentik }\end{array}$ & 68 & 84 & 90 & $\begin{array}{l}\text { Diskusi, unjuk } \\
\text { kerja, bimbingan } \\
\text { online }\end{array}$ \\
\hline 4. & $\begin{array}{l}\text { Pengembangan } \\
\text { instrumen, rubrik } \\
\text { penilaian autentik }\end{array}$ & 66 & 80 & 86 & $\begin{array}{l}\text { Diskusi, unjuk } \\
\text { kerja, bimbingan } \\
\text { online }\end{array}$ \\
\hline
\end{tabular}


DOI: https://doi.org/10.21009/sarwahita.152.07

P-ISSN: 0216-7484

E-ISSN: 2597-8926

Berdasarkan hasil pengamatan dan wawancara yang dilakukan selama workshop berlangsung dapat dinyatakan bahwa para peserta merasa sangat antusias dan sangat senang mengikuti workshop, karena mereka merasa bahwa instrumen penilaian yang disosialisasikan oleh narasumber sangat mudah untuk dipahami, langsung dapat diaplikasikan serta memiliki manfaat yang sangat tinggi untuk meningkatkan penilaian hasil belajar peserta didik.

Hal yang agak sulit untuk dipahami guru selama workshop adalah menentukan bentuk penilaian yang tepat

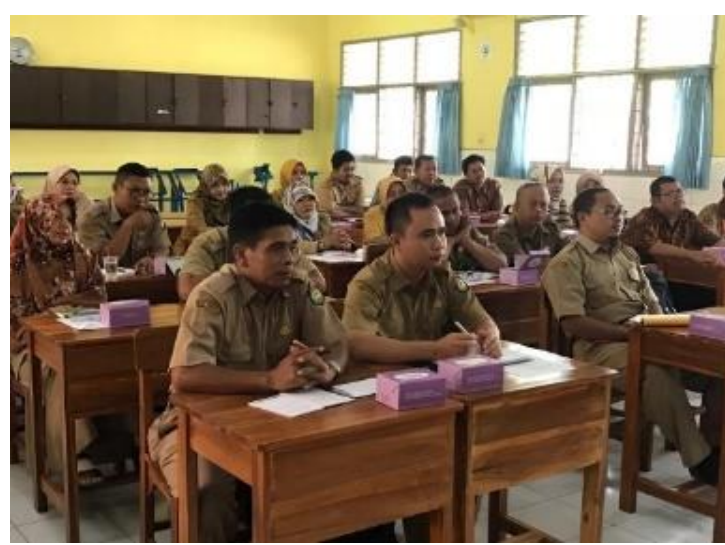

untuk mengukur apakah masalah yang dihadapi bisa dipecahkan atau tidak. Pada awalnya, jenis penilaian yang dibuat guru tidak memiliki benang merah antara masalah yang ingin dipecahkan dengan alat ukur yang dipakai untuk mengukur efektivitas tindakan atau sikap. Tetapi dengan bantuan narasumber dan Tim serta dengan memberikan model atau contoh, guru kemudian mampu untuk membuat jenis penilaian untuk masalah yang mereka alami. Hal ini mereka pecahkan dengan cara diskusi kelompok yang difasilitasi oleh narasumber.

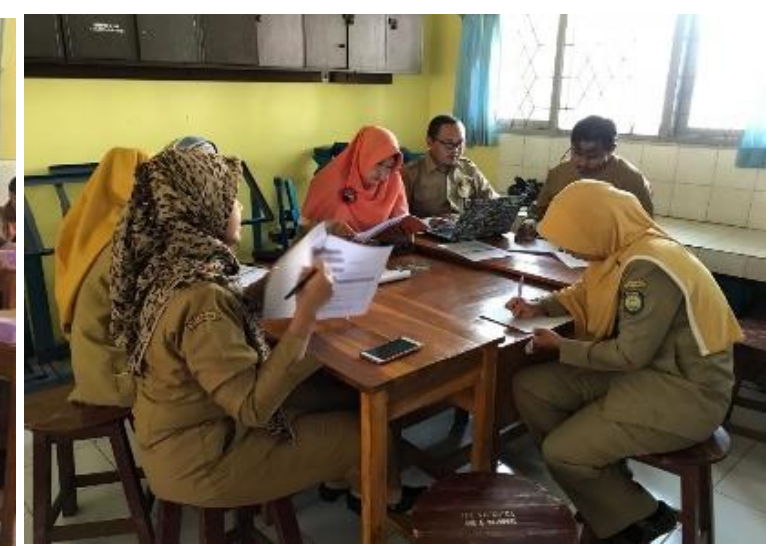

Gambar 3 dan 4. Keseriusan peserta dalam menyimak pemaparan narasumber dan diskusi kelompok menyusun ragam rubrik penilaian autentik

Jenis penilaian yang mereka buat sendiri kemudian didiskusikan dengan teman peserta lain, sehingga mereka bisa membuat bentuk dan jenis penilaian yang tepat dan sesuai dengan masalah yang ingin dipecahkan. Dengan pengetahuan dan mekanisme seperti itu, dapat diharapkan bahwa guru yang mengikuti pelatihan memiliki modal dasar yang kuat untuk meningkatkan proses penilaian pembelajaran yang kontekstual.

\subsection{Hasil Kegiatan}

Hasil kegiatan P2M berupa workshop penilaian autentik bagi guruguru PPKn se-Kabupaten Indramayu ini adalah produk pengetahuan. Produk pengetahuan ini berupa produk tangible dan untangible. Produk untangible berupa pemahaman, motivasi, dan sikap positif peserta workshop terhadap pembuatan instrumen penilaian autentik. Sementara produk yang bersifat tangible berupa instrumen penilaian autentik, 
DOI: https://doi.org/10.21009/sarwahita.152.07

P-ISSN: 0216-7484

E-ISSN: 2597-8926

terutama penilaian afektif dan psikomotorik yang telah dibuat oleh masing-masing peserta workshop. Produk ini masih dikembangkan lebih lanjut (follow up) dalam kegiatan mandiri yang dilakukan peserta kegiatan dan dikirimkan melalui email grup (penilaianauthentik@gmail.com) agar review-nya terbimbing.

Hasil bimbingan yang dilakukan secara online melalui email mencapai harapan yang diinginkan. Guru-guru PPKn SMP se-Kabupaten Indramayu pada perkembangannya selama 2 pekan pendampingan secara online mampu menyusun instrumen penilaian autentik dengan baik (tabel 4).

Tabel 4. Peningkatan Kompetensi Guru Hasil Pendampingan Online

\begin{tabular}{clcc}
\hline No. & \multicolumn{1}{c}{ Muatan Matari } & $\begin{array}{c}\text { Kompetensi Guru Hasil } \\
\text { Pendampingan Online }\end{array}$ & Teknik Penilaian \\
\hline 1. & Konsep dasar penilaian autentik & 93 & Bimbingan online \\
\hline 2. & $\begin{array}{l}\text { Penilaian autentik menurut kurikulum } \\
\text { 2013 }\end{array}$ & 90 & Bimbingan online \\
\hline 3. & $\begin{array}{l}\text { Jenis-jenis dan instrumen penilaian } \\
\text { autentik }\end{array}$ & 90 & Bimbingan online \\
\hline 4. & $\begin{array}{l}\text { Pengembangan instrumen, rubrik } \\
\text { penilaian autentik, dan presentasi hasil } \\
\text { kerja kelompok }\end{array}$ & 86 & Bimbingan online \\
\hline
\end{tabular}

Hasil peningkatan kompetensi pada tabel 4 di atas, sejalan dengan penilaian peserta workshop yang memberikan tanggapan positif atas penyelenggaraan Pengabdian kepada Masyarakat penilaian autentik. Menurut peserta, penyelenggaraan P2M berjalan

Tabel 5. Evaluasi Workshop Peningkatan Kompetensi Guru PPKN SMP dalam Melaksanakan Penilaian Autentik berdasarkan Kurikulum 2013

\begin{tabular}{clcc}
\hline No. & \multicolumn{1}{c}{ Evaluasi } & Puas $(\%)$ & Tidak puas (\%) \\
\hline 1 & Narasumber & 87,33 & 12,67 \\
\hline 2 & Materi yang disajikan & 85,5 & 14,5 \\
\hline 3 & Suasana kegiatan & 87,67 & 12,33 \\
\hline 4 & Sarana prasarana & 86,47 & 13,53 \\
\hline
\end{tabular}

Follow up yang diharapkan oleh peserta dari workshop penilaian autentik adalah diadakan kembali kegiatan serupa dengan jumlah peserta yang lebih banyak, misalnya tingkat kabupaten lancar dan berhasil. Keberhasilan ini tidak hanya diukur dari ketercapaian tujuan workshop, tetapi juga kepuasan peserta terhadap narasumber, materi yang disajikan, suasana dan saranaprasarana. serta dilakukan secara rutin. Dalam workshop lanjutan peserta menginginkan praktik langsung seperti pembuatan multimedia video pembelajaran, penerapan metode up to date dan 
DOI: https://doi.org/10.21009/sarwahita.152.07

P-ISSN: 0216-7484

E-ISSN: 2597-8926

aplikabel pada sekolah sesuai aturan yang ada (sesuai kurikulum 2013). Pentingnya workshop dan pembinaan lanjutan juga diungkapkan dan ditekankan juga oleh Ketua Pengawas Guru PPKn SMP se-Kabupaten Indramayu, Joko Budi Santosa, M.Pd.

\section{PENUTUP}

Penerapan instrumen penilaian autentik sangat diperlukan dan membantu guru dalam melaksanakan penilaian hasil belajar peserta didik. Menguasai teknik dan instrumen penilaian penting bagi guru. Melalui workshop penilaian autentik guru diarahkan menilai seobyektif dan seakurat mungkin. Dengan demikian, guru dapat lebih bersifat adil dalam menilai pencapaian kompetensi peserta didik. Kegiatan Pengabdian kepada Masyarakat penilaian autentik mampu meningkatkan pemahaman guru-guru PPKn SMP di Kabupaten Indramayu.

Hasil kegiatan Pengabdian kepada Masyarakat menunjukkan peningkatan (1) pemahaman peserta mengenai konsep dasar penilaian autentik dengan nilai (84) sesudah workshop dan (93) sesudah pendampingan online; (2) Pemahaman penilaian autentik menurut kurikulum 2013 dengan nilai (87) sesudah workshop dan (90) sesudah pendampingan online; (3) kemampuan mengidentifikasi jenis-jenis dan instrumen penilaian autentik dengan nilai (84) sesudah workshop dan (90) sesudah pendampingan online; (4) pengembangan instrumen, rubrik penilaian autentik (80) sesudah

workshop dan (86) sesudah pendampingan online.

Selain keterbatasan waktu workshop, ada beberapa hal lain yang disarankan oleh peserta antara lain:

1. Perlu adanya workshop lanjutan, aksi/praktik terbimbing, dan pembinaan tentang pembuatan instrumen penilaian autentik.

2. Disarankan kepada guru untuk meneruskan penerapan teknik penilaian autentik dan meningkatkan kemampuan menyusun instrumen penilaian autentik dan memanfaatkan email grup dan millis untuk sarana peningkatan penerapan penilaian autentik.

3. Hendaknya kegiatan semacam ini perlu tindaklanjuti untuk masa yang akan datang dengan persiapan dan agenda yang lebih matang.

4. Pihak Dosen dan pihak Guru diharapkan dapat meningkatkan kerjasama sekaligus mendesain instrumen baku penilaian autentik.

\section{DAFTAR PUSTAKA}

Andika, Tengku. 2011. Restorasi Pendidikan Indonesia.

Yogyakarta: Ar-Ruzz.

Abdullah, 2009. Pengembangan Kurikulum: Teori dan Praktek. Yogyakarta: Ar-Ruzz.

Brookfield, S.D. 1990. The Skillful Teacher: On Technique, Trust, and Responsiveness in the Classroom. San Fransisco : Jossey-Bass.

Dakir, 2004. Perencanaan dan Pengembangan Kurikulum. 
Jakarta: Penerbit PT Rineka Cipta.

Dimyati dan Mudjiono. 2006. Belajar dan Pembelajaran. Jakarta: PT. Rineka Cipta.

Jihad, Asep. 2008. Pengembagan Kurikulum: Tinjauan Teoretis dan Historis. Bandung: Multipressindo.

Killen, Roy. 1998. Effective Teaching Strategies. Katoomba NSW: Social Science Press.

Kunandar. 2011. Guru Profesional: Implementasi Kurikulum Tingkat Satuan Pendidikan (KTSP) dan Sukses dalam Sertifikasi Guru. Jakarta: Rajawali Pers.

Light, G and R. Cox. 2001. Learning and Teaching in Higher Education. London: Paul Chapman Publishing.

Meighan, Roland, dkk. 1981. A Sociology Of education. Pitman Press: London.

Mendikbud. 2016. Permendikbud Nomor 8 Tahun 2016 Tentang Buku Yang Digunakan Oleh Satuan Pendidikan. Jakarta: Kemendikbud. 2016. Permendikbud No. 20 Tahun 2016 Standar Kompetensi Lulusan Sekolah Dasar dan Menengah. Jakarta: Kemendikbud. 2016. Permendikbud No. 21

Tahun 2016 Tentang Standar Isi Pendidikan Dasar dan Menengah. Jakarta: Kemendikbud. . 2016. Permendikbud No. 22

Tahun 2016 Tentang Standar Proses Pendidikan Dasar dan Menengah. Jakarta: Kemendikbud.
. 2016. Permendikbud No. 23 Tahun 2016 Tentang Standar Penilaian Pendidikan. Jakarta: Kemendikbud. 2016. Permendikbud No. 24 Tahun 2016 Tentang Kompetensi Inti dan Kompetensi Dasar Pelajaran Pada Kurikulum 2013 Pada Pendidkan Dasar dan Pendidikan Menengah. Jakarta: Kemendikbud.

Mulyasa. 2013. Pengembangan dan Implementasi Kurikulum 2013. Bandung: PT. Remaja Rosdakarya.

Nasution, S., 2008. Asas-asas Kurikulum. Jakarta: Penerbit PT Bumi Aksara.

Ormiston, M. 2011. Creating a Digitalrich Classroom. Bloomington, IN: Solution Tree Press.

Soedijarto. 1993. Мепији Pendidikan Nasional yang Relevan dan Bermutu, Cetakan ke-4. Jakarta: Balai Pustaka.

Suryadi, A. 1998. Link and Match Kebutuhan

Mendasar Pengembangan SDM. Jurnal Pendidikan dan Kebudayaan. 04, (013).

Suyanto. 2003. "Skenario Pembelajaran", Makalah Disajikan Dalam Semlok Pembelajaran Kontekstual Bagi Guru Pamong Dan Dosen Pembimbing PPL Universitas Negeri Malang: Tanggal $23-24$ Juni 2003 Di UPT PPL Universitas Negeri Malang. Malang: UPT PPL Universitas Negeri Malang. 
DOI: https://doi.org/10.21009/sarwahita.152.07

P-ISSN: 0216-7484

E-ISSN: 2597-8926

Republik Indonesia, Peraturan Pemerintah Republik Indonesia Nomor 19 Tahun 2005 Tentang Standar Nasional Pendidikan, Jakarta: Badan Standar Nasional Pendidikan, 2006.

Republik Indonesia, Undang-Undang Republik Indonesia No. 20 Tahun 2003 tentang Sistem Pendidikan Nasional, Jakarta: Penerbit Sinar Grafika, 2005.

Robinson, Philip. 1981. Perspective on The Sociology of Education: an Introduction, diterjemahkan oleh Hasan Basari (ed) 1986. Beberapa Prespektif Sosioligi Pendidikan Philip Robinson. Jakarta: Rajawali.

untuk Merencanakan dan Menyampaikan Pengajaran. Jakarta: Grasindo.

Tim LPPM UNJ. 2018. Panduan Penelitian dan Pengabdian Kepada Masyarakat. Jakarta: LPPM UNJ.

Turner, Jonatan H. 1998. The Stucture of Sociological Theory: Sixth Edition. California: Wadsworth Publising Company.

Utomo, Tjipo dan Kees Ruijter. 1991. Peningkatan an Pengembangan Pendidikan. Jakarta: Gramedia Pustaka Utama.

Yulaelawati, Ella, 2004. Kurikulum dan Pembelajaran. Bandung : Pakar Raya.

Rooijakkers, Ad. 1991. Mengajar dengan Sukses: Petunjuk Umum 